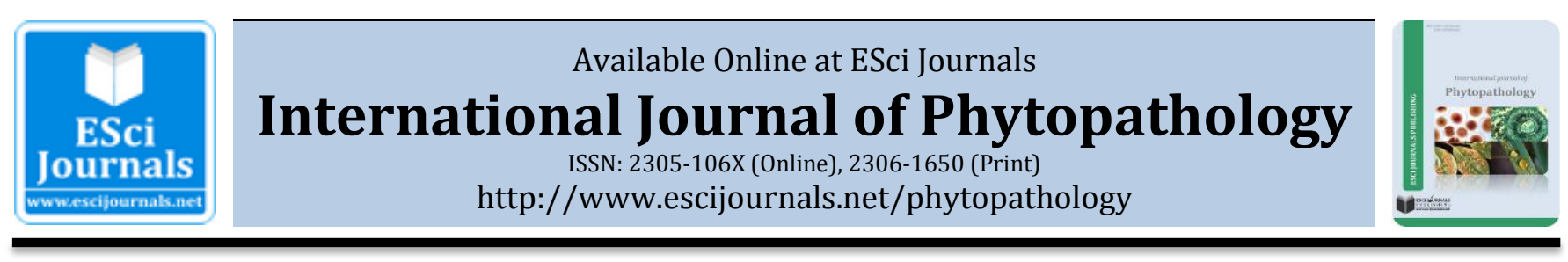

\title{
VARIABILITY OF COLLETOTRICHUM GLOEOSPORIOIDES ISOLATES THE CAUSAL AGENT OF ANTHRACNOSE DISEASE OF CASSAVA AND YAM PLANTS IN GHANA
}

\author{
aAppiah-Kubi Zippora, bApetorgbor A. Kofi, aMoses Emmanuel, aAppiah-Kubi David, aMarfo Esther \\ a CSIR-Crops Research Institute, Plant Health Division. Kumasi, Ghana. \\ b Department of Theoretical and Applied Biology, KNUST, Kumasi, Ghana.
}

\begin{abstract}
A B S T R A C T
Cassava and yam plants are important staple foods of millions of people in the tropical world and provide food security in most parts of sub-Saharan Africa. Their production however is affected by anthracnose disease caused by Colletotrichum gloeosporioides, (Penz.) Penz. and Sacc contributing to 30-70\% economic loss in both crops. A study was carried out to determine if variations exist between isolates of $C$. gloeosporioides on the two crops occurring in different agro-ecological zones of Ghana. Anthracnose-diseased samples of cassava and yam plant parts (leaves and stem/vine) were collected from four agro-ecological zones of Ghana (Forest, Forest-Savannah Transition, Guinea and Coastal Savannah). Isolations of the causal organism C. gloeosporioides were made. The isolates were investigated on the basis of growth characteristics on Potato Dextrose Agar (PDA): presence or absence of setae, colour of cultures, dimensions of conidia. Pathogenicity of isolates was determined and molecular analysis conducted using Random Amplified Polymorphic DNA (RAPD). Results showed both similarities and variations in cultural, morphological and growth characteristics of the pathogen. Isolates from yam caused pathogenic lesions on cassava and yam plant sections and vice versa. Forty-four isolates of $C$. gloeosporioides from cassava and yam compared by RAPD analysis grouped the isolates into three main clusters. Within two of the clusters are six polymorphic sub-groups relating to host and geographical origin. The different polymorphic sub-groups indicated that there are several sub-populations of $C$. gloeosporioides isolates, which either singly or in association, involved in the yam and cassava anthracnose infections in the field. Isolates from different ecological zones, with similar morphological features, clustering in a polymorphic sub-group suggest a common origin for some of them.
\end{abstract}

Keywords: Cassava, yam, anthracnose, Colletotrichum gloeosporioides, agro-ecological zones.

\section{INTRODUCTION}

Cassava (Manihot esculenta) is an important staple food of millions of inhabitants in the tropical world contributing immensely to food security of the rural poor (FAO, 2007). It is the principal carbohydrate source for more than 600 million people in the tropical world (FAO, 2002). The crop is adapted to various harsh environmental conditions and does well in even marginal soils (Nweke et al., 1999). As a food security crop for smallholder farmers, particularly in low-income, food-deficit countries, owing to its reputation for reliability, cassava is grown in most West African countries. The crop has the potential to increase farm incomes, reduce rural and urban poverty and help close

* Corresponding Author:

Email: zipak1@yahoo.com

(C) 2014 ESci Journals Publishing. All rights reserved. the food gap (Nweke et al., 2002).

Yams (Dioscorea spp.) are also important food crops depended on for food security in most parts of sub-Saharan Africa (Babaleye, 2003). Yam tubers can be stored for up to six months at ambient temperatures. This characteristic contributes to the substance of food supply and improvement of food security. The crop is a reliable source of income to both producers and traders as it has high market value in Europe and the Americas (Sahore and Kamenan, 2007; IITA, 2007). Yams are virtually produced for human food and are higher in protein and minerals like phosphorus, potassium and vitamin C compared to cassava (Scott et al., 2000). The crop plays a significant role in the socio-cultural lives of some producing regions as evidenced by numerous New Yam Festivals celebrated by various ethnic groups in most of West Africa in the celebrated New Yam Festival in West Africa (Orkwor, 1998). 
Despite the great importance of these two crops, efforts of farmers to increase or sustain yields are greatly affected by a number of constraints including diseases and pests. Anthracnose disease of cassava and yam caused by the fungus Colletotrichum gloeosporioides causes losses that range between $30-70 \%$ (Moses and Lamptey, 2001) of harvested crops.

The most outstanding effect of cassava anthracnose is its ability to cause severe cankers on stem, necrosis and wilting of leaves and diebacks. Badly infected stems become brittle and break easily under strong winds resulting in the reduction of healthy planting materials to farmers (Hahn et al., 1989). Yam anthracnose causes leaf necrosis and dieback of vines, leading to a reduction in the effective photosynthetic surface area of the crop. This leads to reduction in food reserves (Abang et al., 2003). Anthracnose may also produce round, water soaked and sunken brownish spots or concentric ring patterns by the conidial masses. Severe infection results in defoliation, vine dieback and tuber dry rot (Fokunang et al., 2000). The disease therefore constitutes a great constraint to production, safe international germplasm exchange and conservation.

Information on whether or not the same strain of $C$. gloeosporioides of cassava causes anthracnose on yam and cassava plants and vice versa is not clear. There is the need therefore to characterise the isolates of $C$. gloeosporioides from the two crops and establish if they are the same and they are host or non-host, or agroecologically specific in their attack or not. The nonspecific nature of $C$. gloeosporioides infections has been reported in strawberry (Freeman et al., 2000).

\section{MATERIALS AND METHODS}

Collection of Cassava and Yam plant parts and isolation of the pathogens: Samples of leaf, vine and stem tissues with typical symptoms of anthracnose were collected from farms in four agro-ecological zones of Ghana. Collections were made from Tata, Koforidua, Kyekyewere in the Nkawie District in the Forest zone; Dromankuma, Hiawoanwu, Asoman in the Ejura District in the Transition zone; Nabori, Sori No, Agric Settlement in the Damongo District in the Guinea Savannah zone; and, Fianko, Ackon, Obrachire in the Effutu municipal District in the Coastal Savannah zone. The distance between two nearest locations of sample collection was 20-30 km apart.

Isolation of pathogens and production of single spore cultures were carried out using the procedure of Erwin and Ribeiro (1996). Pieces of diseased tissues were surface sterilized by immersion in $5 \%$ sodium hypochlorite $(\mathrm{NaOCl})$ solution for $5 \mathrm{~min}$ followed by washing (three times) in sterilized distilled water. They were then dried in a sterile Lamina flow hood, placed on Potato Dextrose Agar (PDA) in Petri dishes and incubated at $28 \pm 2^{\circ} \mathrm{C}$. On the fourth day, the samples were examined individually for the growth of $C$. gloeosporioides under (different magnifications of) stereo binocular microscope. The identification of the fungi was based on habit and morphological characters of the fruiting bodies. Slides of the fruiting structures were prepared, and spores/conidia of the fungus observed under different magnifications of compound microscope.

Mycelial growths from the plated tissues were transferred (picked with flamed needle from the periphery of growth) to fresh PDA plates. Sub-culturing was carried out to obtain pure isolates which were maintained on PDA. They were put under Near Ultra Violet (NUV) light for one week to induce spore formation.

Spore suspensions of the isolates were produced by adding $10 \mathrm{ml}$ sterile distilled water to the cultures followed by gentle surface agitation with a flamed inoculation needle. They were serially diluted from $1 \mathrm{x}$ $10^{-1}$ to $1 \times 10^{-5}$. From each of the $1 \times 10^{-4}$ and $1 \times 10^{-5}$ spore suspensions, $100 \mu \mathrm{l}$ were pipetted and spread on the surface of freshly prepared water agar in $9 \mathrm{~cm}$ diameter Petri dishes. After twenty four hours, sterile inoculation needles were used to gently pick germinating single conidia of C. gloeosporioides onto freshly prepared PDA plates. The plates were incubated under alternating cycles of NUV light and darkness at $28 \pm 2{ }^{\circ} \mathrm{C}$ for one week. The cultures produced were maintained on PDA (Smith and Onions, 1994).

Cultural characterization of $C$. gloeosporioides isolates: Mycelial discs of seven-day-old cultures of isolates were inoculated on PDA. The plates were incubated at $28 \pm 2^{\circ} \mathrm{C}$ and observed for four weeks. Growth characteristics and pigments produced by the isolates during incubation were noted. Diameter of mycelia growth of each isolate was measured (at twentyfour hour interval) for five days.

To seven-day-old cultures of isolates, $10 \mathrm{ml}$ sterile distilled water was added to produce spore suspensions. The length and width of conidia produced by representative isolates were measured using the slide 
and ocular micrometer scale under a compound microscope. For each isolate a total of 50 conidia were measured and the mean determined.

Similarities in spore characteristics of isolates obtained from the two crops as well as from the different agroecological zones were recorded.

Pathogenicity test of isolates on plant parts: Spore suspension of representative isolates of $C$. gloeosporioides from yam and cassava plant parts were produced from 7-day-old cultures on PDA. Fifty millilitres $(50 \mathrm{ml})$ of spore suspension was used to inoculate $50 \mathrm{ml}$ Czapex Dox liquid medium and incubated at $28 \pm 2{ }^{\circ} \mathrm{C}$ on an orbital shaker (Flask shaker SF1) at $100 \mathrm{rpm}$ for 72 hours. Spores produced were harvested by filtration through sterile muslin cloth and centrifugation at $13,000 \mathrm{rpm}$. Concentrations of the harvested spores were adjusted to $1 \times 10^{-7}$ spores per $\mathrm{ml}$ using sterile distilled water.

Healthy tissues of cassava stems and leaves, yam vines and leaves to be inoculated were surfaced sterilized with $5 \%$ sodium hypochlorite and then washed three times in sterile distilled water. The surfaces of the healthy tissues were inoculated with $50 \mu \mathrm{l}$ of $1 \times 10^{-7}$ spore suspension of each representative isolate. Healthy tissues inoculated with $50 \mu$ l sterile distilled water served as control. There were four replicates of each plant part. The inoculated tissues were kept in humidity chambers maintained at $28 \pm 2^{\circ} \mathrm{C}$. After three days of inoculation, the tissues were observed daily for the appearance of disease symptoms. Symptoms observed ranged from tiny dead spots to large circular or irregular dead blotches. On the vines, the dead areas merged until the whole tissue dies. All the tissues inoculated showed $100 \%$ incidence of infection.

After two weeks of inoculation, following procedure from (Erwin and Ribeiro, 1996). The infected tissues were cultured, examined and C. gloeosporioides isolated. Koch's postulate was fulfilled by re-isolation of $C$. gloeosporioides from the inoculated samples. Spore shape, size and colony morphology were identical for the original and the recovered isolates.

DNA extraction from mycelia: Spore suspension of each the 44 C. gloeosporioides isolates from cassava and yam were produced from 10-day-old single spore cultures on PDA. Five hundred microlitres $(500 \mu \mathrm{l})$ of each spore suspensions was used to inoculate $100 \mathrm{ml}$ V8 Czapek Dox liquid medium and maintained at $28^{\circ} \mathrm{C}$ on an orbital shaker (Flask shaker SF1) at $100 \mathrm{rpm}$.
Mycelia were harvested after 48 hours (Sutton, 1992; Mill et al., 1992; Mordue, 1991).

Hundred milligrams (100 mg) of mycelium from each isolate was frozen in liquid nitrogen and ground to powder. DNA was extracted using a modified protocol for DNA extraction from plant tissue using a commercial QIAGEN extraction kit; (Lee and Taylor, 1990). The genomic DNA estimated was re-suspended in 50 $\mathrm{\mu l}$ Tris-EDTA $(10 \mathrm{mM}$ Tris- $\mathrm{HCl}$ [pH 8.0$], 1 \mathrm{mM}$ EDTA) and stored in a freezer until required (http://academicjournals.org).

DNA amplification with Random Primers: Eight oligonucleotides:

RP2-5'CCTGGGCTTG3'; RP15-5'CCTG GGTTTG3'; RP95-5'GGGGGGTTGG3'; RP4-5'CCTGGGCTGG3'; RP85-5'GTGCTCGTGC3'; RP362- 5'CCGCCTTACA3'; RP400- 5'GCCCTGATAT 3'; were used for Randomized Amplification Polymorphic DNA (RAPD) analysis. PCR amplifications were carried out in $25 \mu \mathrm{l}$ mixture containing $2 \mu \mathrm{l}$ of genomic DNA, $25 \mathrm{mM} \mathrm{MgCl}_{2} 0.9 \mu \mathrm{l}, 10 \times$ PCR buffer $1 \mu \mathrm{l}, 10 \mathrm{mM}$ each of dNTP $0.4 \mu \mathrm{l}, 0.05$ of Taq DNA polymerase (Biolab) and $0.5 \mu \mathrm{l}$ of primer.

The reaction mixtures were incubated on a DNA thermocycler (Gen Amp® PCR system 9700 version 3.09). The PCR profile denaturation was at $94^{\circ} \mathrm{C}$ for $3 \mathrm{~min}$, followed by 35 cycles of $30 \mathrm{sec}$ at $94^{\circ} \mathrm{C}, 30 \mathrm{sec}$ at $45^{\circ} \mathrm{C}$ and $1 \mathrm{~min}$ at $72^{\circ} \mathrm{C}$, and then a $10 \mathrm{~min}$ extension at $72^{\circ} \mathrm{C}$. PCR products from the RAPD were separated in a $1.5 \%$ agarose gel, stained with ethidium bromide, viewed and photographed on a UV transilluminator (Xiao et al., 2004; Vinod and Benagi, 2009). The multiple and single RAPD bands produced were scored manually and analyzed as binary data. The presence or absence of monomorphic and polymorphic bands was scored 1 and 0 respectively, and the results obtained for all primers were pooled in a single matrix for analysis.

The Numerical Taxonomy System Applied Biostatistics, Inc (NTSYS) PC software (Rholf, 1994) was used for analysis of the genetic similarity of isolates based on Randomized Amplification Polymorphic DNA (RAPD). The data were analyzed as a binary matrix, from which a similarity matrix was built using the Darwin v5Jaccard coefficient (Jaccard, 1908). Data from the similarity matrix were used to produce a dendogram using the unweighted pair group method with arithmetic mean (UPGMA). 


\section{RESULTS AND DISCUSSION}

Cultural characteristics of $C$. gloeosporioides isolates: Change in colour of media in which isolates were cultured varied from pink, pale pink, pale orange to dark brown while setae were either present or absent on cultures of both yam and cassava (Table 1). Isolates from the forest zone, from both cassava and yam had circular growth pattern with no setae whilst media were pale orange. This suggests that the isolates may be similar or same and occurs on both yam and cassava in the different ecologies.

Table 1. Cultural characteristics of yam and cassava isolates of $C$. gloeosporioides.

\begin{tabular}{|c|c|c|c|c|c|c|}
\hline \multirow{3}{*}{$\begin{array}{l}\text { Ecological zone } \\
\text { and sample code }\end{array}$} & \multicolumn{6}{|c|}{ Characteristics of Isolates from } \\
\hline & \multicolumn{3}{|c|}{ Yam } & \multicolumn{3}{|c|}{ Cassava } \\
\hline & $\begin{array}{l}\text { Growth } \\
\text { Pattern }\end{array}$ & $\begin{array}{l}\text { Media } \\
\text { colour }\end{array}$ & Setae & $\begin{array}{l}\text { Growth } \\
\text { Pattern }\end{array}$ & Media Colour & Setae \\
\hline \multicolumn{7}{|l|}{ Forest } \\
\hline F1 & Circular & Pale orange & Absent & Circular & Pale orange & Absent \\
\hline $\mathrm{F} 2$ & Circular & Pale orange & Absent & Circular & Pale orange & Absent \\
\hline F3 & Circular & Pale orange & Absent & Circular & Pale orange & Absent \\
\hline \multicolumn{7}{|l|}{ Transition } \\
\hline $\mathrm{T} 1$ & Circular & Pink & Absent & Wavy & Pale pink & Absent \\
\hline T2 & Wavy & Dark brown & Present & Wavy & Dark brown & Present \\
\hline T3 & Circular & Pale pink & Absent & Circular & Pale pink & Absent \\
\hline \multicolumn{7}{|l|}{ Guinea } \\
\hline GS1 & Wavy & Pale orange & Absent & Circular & Pink & Present \\
\hline GS2 & Circular & Pale orange & Absent & Circular & Pink & Absent \\
\hline GS3 & Wavy & Pale pink & Absent & Wavy & Pale pink & Absent \\
\hline \multicolumn{7}{|l|}{ Coastal } \\
\hline CS1 & Circular & Pale orange & Absent & Wavy & Pale pink & Present \\
\hline CS2 & Circular & Pale orange & Absent & Circular & Pale pink & Absent \\
\hline CS3 & Circular & Pale orange & Absent & Wavy & Dark brown & Present \\
\hline
\end{tabular}

Two growth patterns were observed: wavy, with mycelia growing in a concentric manner showing zonation and, circular, with mycelia showing uniform concentric growth with zonation and smooth edges (Plate 1). Cultures of both growth patterns produced bright orange or pink spore masses at the centre as well as the

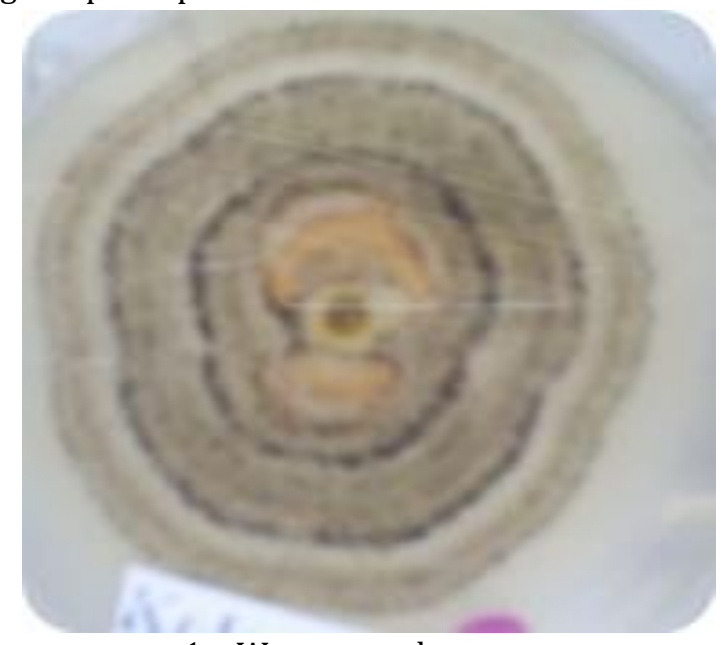

1a: Wavy growth pattern periphery of the colonies. In addition, those with the wavy growth pattern produced black acervuli with setae around the centre of the colony. Tjamos et al., Tjanos et al. (1993) however reported considerable variations among isolates of $C$. gloeosporioides with respect to colony and morphology.

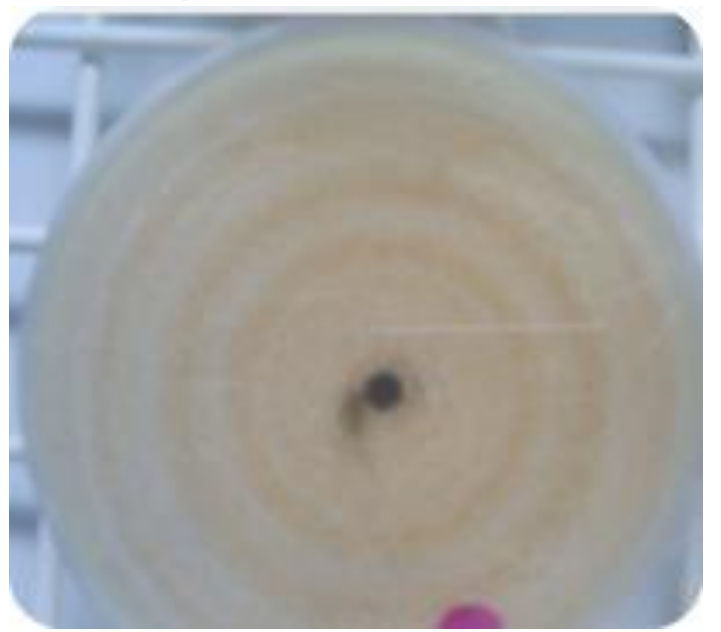

1b: Circular growth pattern

Plate 1 (a and b). Wavy (1a) and circular (1b) growth of C. gloeosporioides cultures on PDA at 28oC for 7 days. 
Conidia were ovoid or oblong-shaped (Plate 2). Conidia size (length and width) showed differences between $C$. gloeosporioides isolates from cassava and those from yam (Table 2). Conidia of $C$. gloeosporioides isolates from yam were significantly longer and broader $(P \leq 0.05)$ than those from cassava, keeping them in two different groups. This finding is in agreement with that by Photita et al. (2005) who found that spore sizes were significantly different for

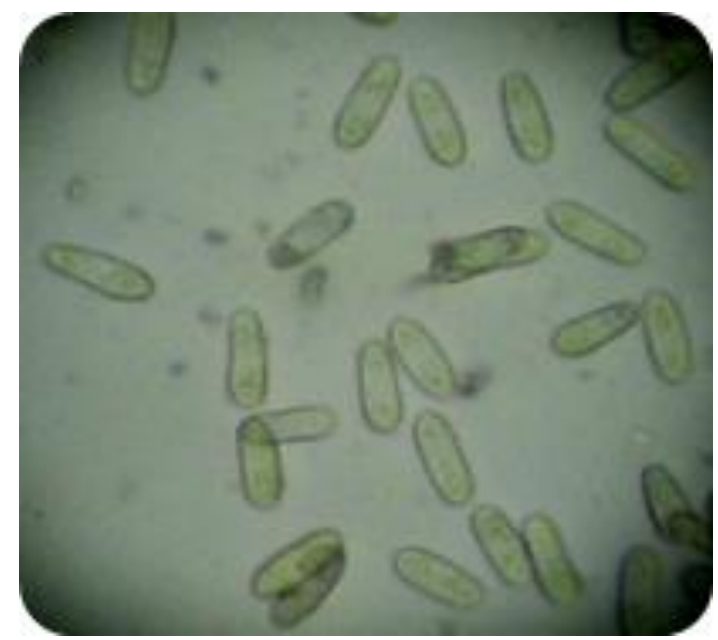

2a: Conidia of C. gloeosporioides from yam
C. gloeosporioides isolated from different crops. Spores of isolates from yam in all the ecological zones were also wider than those from cassava although the differences were not significant. Conidia size of the isolates from yam decreased from the Forest through the Transition and Guinea figure Savannah to the Coastal savannah zones, which could be attributed to levels of humidity and other environmental conditions prevailing in these ecologies.

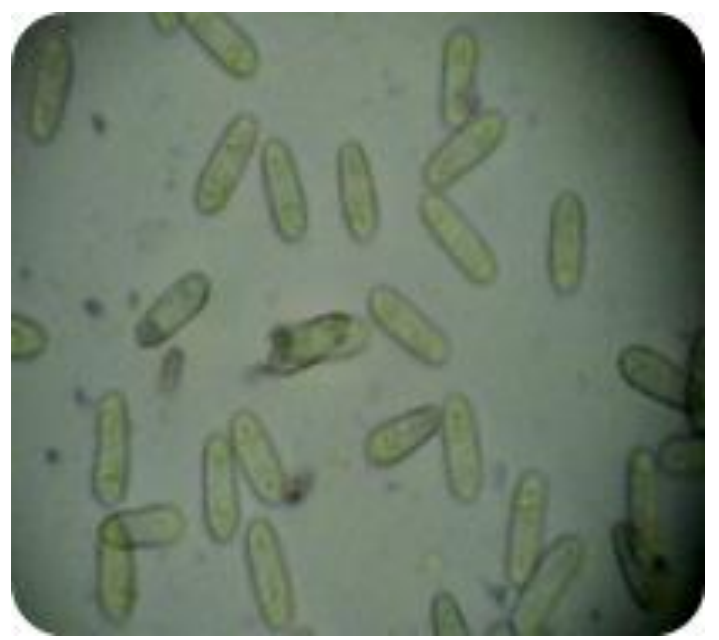

2b: Conidia of C. gloeosporioides from cassava

Plate 2 ( $a$ and b). Conidia of C. gloeosporioides from yam (2a) and cassava (2b) plants as seen under microscope (X40).

Table 2. Conidial length and width of Colletotrichum gloeosporioides isolates from cassava and yam from four agroecological zones of Ghana.

\begin{tabular}{lccccc}
\hline \multirow{2}{*}{ Ecological zone } & \multicolumn{3}{c}{ Dimension of conidia (Mean \pm SE) obtained from } \\
\cline { 2 - 3 } \cline { 2 - 3 } \cline { 5 - 6 } & \multicolumn{2}{c}{ Yam } & & \multicolumn{2}{c}{ Cassava } \\
\cline { 2 - 3 } \cline { 5 - 6 } Forest & $16.07 \pm 0.04$ & $4.16 \pm 0.02$ & & $13.97 \pm 0.05$ & $3.95 \pm 0.01$ \\
Transition & $15.59 \pm 0.05$ & $4.11 \pm 0.01$ & & $14.28 \pm 0.05$ & $4.00 \pm 0.01$ \\
Guinea & $15.37 \pm 0.04$ & $4.03 \pm 0.01$ & & $11.99 \pm 0.05$ & $3.88 \pm 0.01$ \\
Coastal & $15.09 \pm 0.05$ & $3.99 \pm 0.01$ & & $13.31 \pm 0.05$ & $3.79 \pm 0.01$ \\
\hline Grand mean & 15.52 & 4.07 & & 13.42 & 3.91 \\
\hline LSD & 0.049 & 0.013 & & 0.049 & 0.013 \\
\hline CV \% & 0.6 & 0.5 & & 0.6 & 0.5 \\
\hline
\end{tabular}

Pathogenicity of isolates on plants: Isolates of $C$. gloeosporioides caused development of brown lesions on the inoculated vines and leaves of yam as well as on the stems and leaves of cassava. Isolates from both cassava and yam caused similar lesions on the plant parts (Plates 3 and 4).

The brown lesions on the yam leaf surface in particular looked like anthracnose lesions on an infected yam plant. This observation confirms findings of other workers (Serra et al., 2008; Abang et al., 2006; Xiao et al., 2004) that C. gloeosporioides is non-specific in its attack. Existence of this situation in the field can contribute to high incidence and persistence of anthracnose diseases in agro-ecological zones where cassava and yam inter-cropping are practiced. The cross-infection potential of $C$. gloeosporioides isolates from yam and cassava shown is an indication that $C$. gloeosporioides isolates from cassava could cause pathogenic lesions on yams and vice versa. In Ghana, where mixed cropping is a common practice, it is likely 
that $C$. gloeosporioides spores from yam are increasing the incidence and severity of cassava anthracnose and vice versa. Each of the two crops may have the potential to act as a reservoir of anthracnose-causing

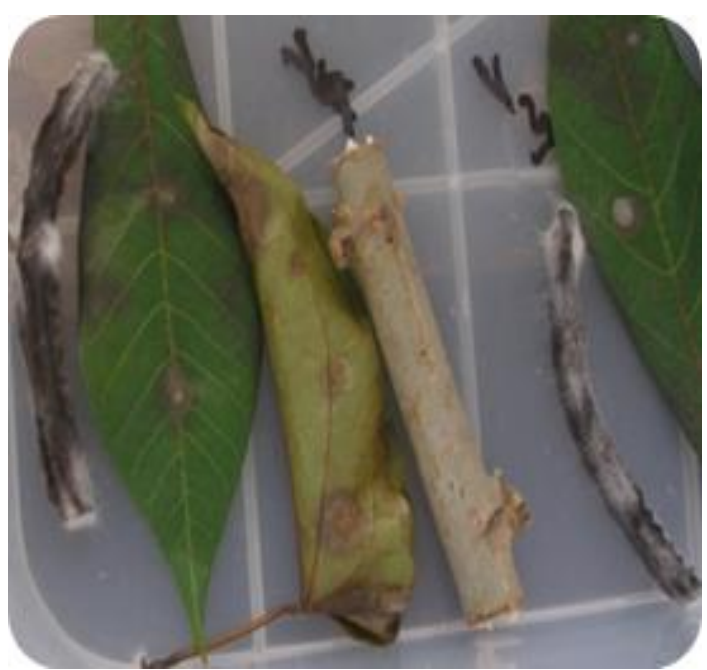

inoculums on cassava and yam fields. To reduce the cross-infection potential of $C$. gloeosporioides, care has to be taken in intercropping these two crops since each of them is susceptible to C. gloeosporioides.

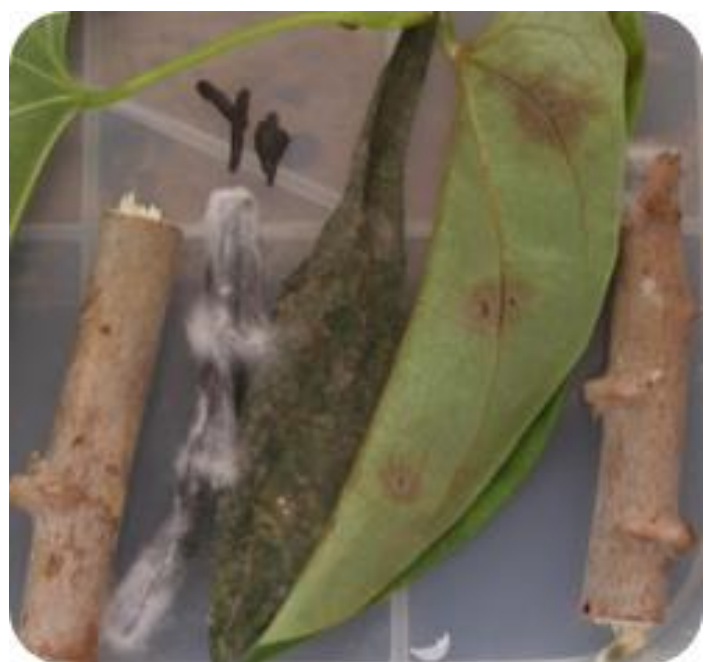

Plate 3. Lesions (arrowed) formed when spores of isolates from yam were inoculated on surfaces of leaves, stems and vines of yam and cassava.
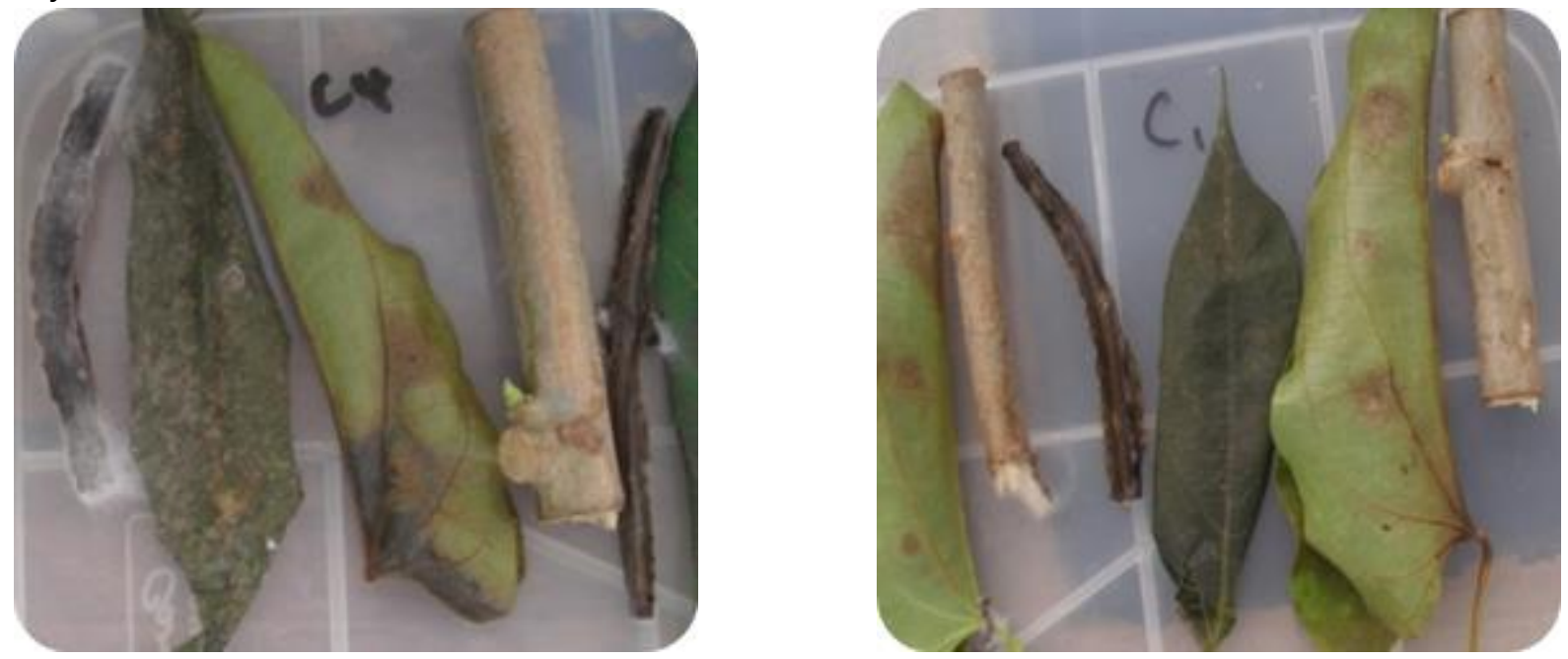

Plate 4. Lesions (arrowed) formed when spores of isolates from cassava were inoculated on the surfaces of leaves, stems and vines of yam and cassava.

Molecular analysis: RAPD amplifications using the eight oligonuclotide primers yielded scorable bands for all the isolates of the fungal species. The banding pattern varied, with primers RP2, RP4, RP95, RP15, RP85, RP346 and RP368 producing multiple bands (polymorphic) while primer RP400 produced only a single band (monomorphic) (Figure 1).

The dendrogram obtained from the cluster analysis of RAPD data portrayed three distinct groups of the fortyfour C. gloeosporioides isolates from cassava and yam (Figure 2). The first cluster (A) comprises four subclusters: A1, A2, A3 made up of seventeen $C$. gloeosporioides isolates, all from cassava and A4 with five C. gloeosporioides isolates from cassava and three from yam. The second cluster (B) consists of two sub-clusters B1 and B2 with eighteen C. gloeosporioides isolates all from yam. Cluster $\mathrm{C}$ contains a single isolate $\mathrm{C} 43 \mathrm{~b}$ from cassava which is clearly distinct from the others (Table 3 ). The five sub-groups, A1, A2 and A3 comprising cassava isolates only and B1 and B2 comprising yam isolates only, is an indication that isolates from the two crops are genetically distinct. Composition of these five subclusters also suggests that the isolates may be host and location specific. 


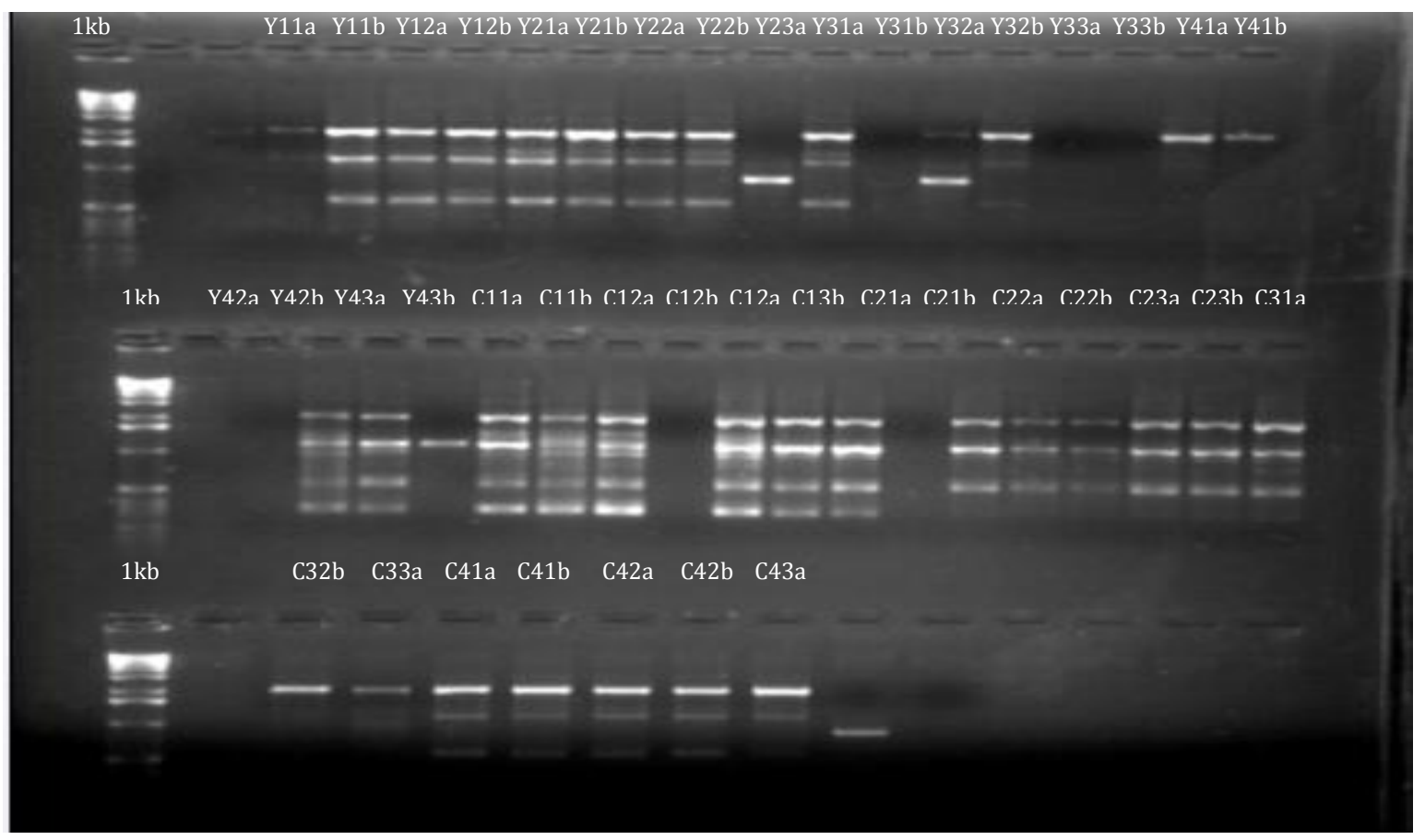

Figure 1. RAPD profile of C. gloeosporioides generating multiple bands with primer RP4.

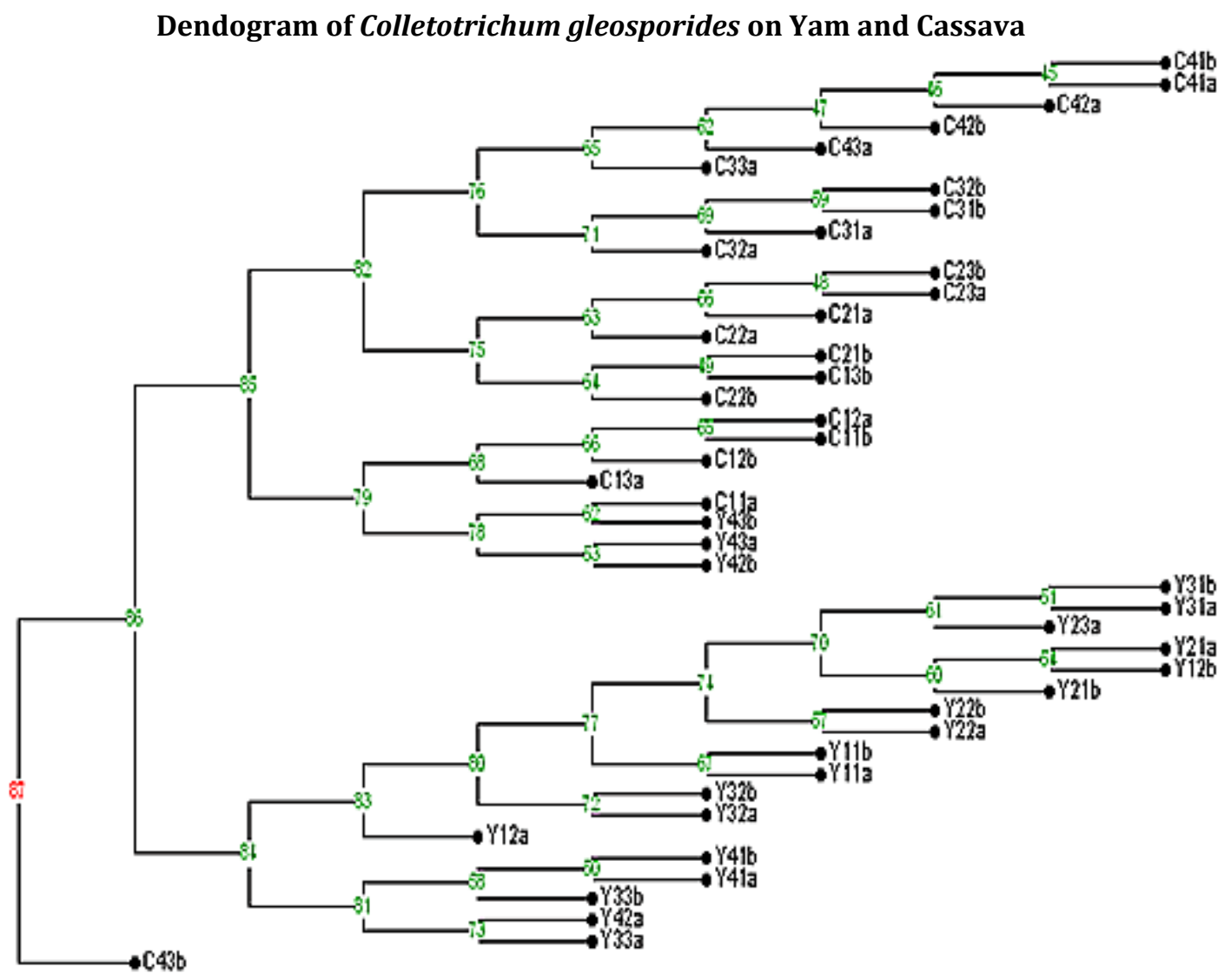

Figure 2. Dendrogram showing genetic similarity between C. gloeosporioides isolates from cassava and yam based on RAPD profile. 
Int. J. Phytopathol. 05 (01) 2016. 01-09

Table 3. The three clusters of Colletotrichum gloeosporioides obtained from RAPD analysis.

\begin{tabular}{ccc}
\hline Cluster A & Cluster B & Cluster C \\
\hline Sub-group A1 & Sub-group B1 & C43 \\
\hline C41a, C41b, C42a, & Y31b, Y31a, Y23a, Y21a, Y12b, & - \\
C42b, C43a, C33a & Y22b, Y22a, Y11b, Y11a & - \\
\hline Sub-group A2 & Sub-groups B2 & - \\
\hline C32b, C31b, C31a, C32a & Y32b, Y32a, Y12a, Y41b, Y41a & - \\
\hline Sub-group A3 & Y33b, Y42a, Y33a, & - \\
\hline C32b, C23a, C21a, C22a & - & - \\
C21b, C13b, C22b, & - & - \\
Sub-groups A4 & - & - \\
C12a, C11b, C12b, C13a & - & - \\
C11a, Y43b, Y43a, Y42b & - & - \\
\hline
\end{tabular}

Sub-cluster B4, comprising isolates from cassava from the Forest zone and isolates from yam from the Coastal savannah zone suggested that these isolates could be genetically identical. This situation is also an indication that some isolates from cassava are genetically similar to isolates from cassava than those from the same crop and vice versa.

This finding suggests that isolates in this group should not be considered as separate species. The isolates in this group, having identical genetic banding patterns indicate common ancestry, but differing in their host preference, may imply adaptation to the different crops as has been suggested by Martín ez-Culebras et al. (2002). Similarities observed in the group also suggest geographic migrations where one of them might have been introduced from a different location. Migrations of C. gloeosporioides has been reported by Photita et al. (2005). It is also possible that these isolates are the most frequently occurring on cassava and yam because of their ability to survive on the different hosts.

\section{CONCLUSION}

Cultural, morphological and pathogenic variability could be preliminary parameters for characterizing Colletotrichum gloeosporioides. With diversity in morphological characters; conidial measurements, , radial growth patterns, mycelial colour in culture and the presence or absence of setae, it is obvious that there are several sub-populations of isolates of $C$. gloeosporioides, either singly or in association, involved in the cassava and yam anthracnose infections in the field. Also, the similarities shown among some of the isolates from the four ecological zones of Ghana suggest a common origin for some of them. These criteria alone, however, are not always adequate for species identification of $C$. gloeosporioides due to overlapping in morphological characters and phenotypic variation among species under different environmental conditions. The results of the RAPD analyses of C. gloeosporioides isolates pathogenic on cassava and yam separated isolates from yam from those from cassava. However, with the sub-group in which some isolates of cassava were genetically closer to those from yam than isolates from cassava, it is possible that they are the same and could have the pathogenic effect on these two important crops.

\section{REFERENCES}

Abang, M. M., R. Asiedu, P. Hoffmann, G. A. Wolf, H. D. Mignouna and S. Winter. 2006. Pathogenic and genetic variability among Colletotrichum gloeosporioides isolates from different yam hosts in three agroecological zones in Nigeria. Journal of Phytopathology 154: 51-61.

Abang, M. M., S. Winter, H. D. Mignouna, K. R. Green and R. Asiedu. 2003. Molecular, taxonomic, epidemiological and population genetic approaches to understanding yam anthracnose disease. African Journal of Biotechnology 2 (12): 486-496.

Babaleye, T. 2003. West Africa: Improving yam production technology, ANB-BIA Supplement Issue/ Edition $\mathrm{Nr} 463$.

Erwin, D. C. and O. K. Ribeiro. 1996. Phytophthora diseases worldwide. APS Press. Pp xii +562 .

FAO 2002. Agriculture data. Food and Agriculture Organization of the United Nations.

FAO 2007. Food and Agricultural Organisation of the United Nations. FAO Statistics.

Fokunang, C. N., T. Ikotun, C. N. Akem, A. G. O. Dixon, E. A. Tembe, and P. Koona. 2000. Investigation of inoculum threshold and latent infection in Colletotrichum gloeosporioides f.sp. manihotis in cassava cultivars. Pak. J. Biol. Sci. 3(5): 713-716. 
Freeman, S., E. Shabi and T. Katan. 2000. Characterization of Colletotrichum acutatum causing anthracnose disease of anemone (Anemone coronaria L.) Appl. Environ. Microbiol. 66:5267-5272.

Hahn, S. K., J. C. G. Isoba and T. Ikotun. 1989. Resistance breeding in root and tuber crops at International Institute of Tropical Agriculture, Ibadan, Nigeria. Crop Protection 23: 78 - 82.

IITA. 2007. Yam research for development. IITA Publication 1: 1-10.

Jaccard, P. 1908. Nouvelles recherches sur la distribution florale. Bul. Soc. Vaudoise Sci. Nat. 44: 223-270.

Lee, S. B., J. and W. Taylor. 1990. Isolation of DNA from fungal mycelia and single spores. In: Innis M, A., Gelfand DH, Sninsky J. J., White T. J., eds. PCR protocols: a guide to methods, applications. San Diego: Academic Press. 282-287.

Martin ez-Culebras, P. V., A. Querol, M. B. SuarezFernandez, M. D. Garcia-Lopez and E. Barrio. 2002. Phylogenetic relationships among Colletotrichum pathogens of strawberry and design of PCR primers for their identification. Journal of Phytopathology 22: 85-89.

Mill, P. R., S. Sreenivasaprasad and E. A. Brown. 1992. Detection and differentiation of Colletotrichum gloeosporioides using PCR, FEMS. Microbial. Lett. 98:137-144.

Mordue, J. E. M. 1971. Glomerella cingulata: Description of pathogenic fungi and bacteria, No.315. Commomwealth Mycological Institute, Kew, Surrey, England.

Moses, E. and J. N. L. Lamptey. 2001. Report on pest and disease surveillance survey for the dry season of 2001. RTIP/CRI Report.

Nweke, F. I., D. Spencer and J. Lynam. 2002. The cassava transformation: Africa's best- kept secret. Michigan State University Press, East Lansing. 196.

Nweke, F. I., J. Haleegoah, A. Dixon, G. Ajobo, B. Ugwu and R. Al-Hassan. 1999. Cassava production in Ghana. A function of market demands and access to improve production and processing technology. Collaborative Study of Cassava in Africa. OSCA, Working Paper No 21, IITA, Ibadan, Nigeria.

Orkwor, G. C. 1998. The importance of yams. In: Food yams: Advances in research. Orkwor, G. C., Asiedu, R., Ekanayake, I. J. (eds). IITA, Ibadan,
Nigeria and NRCRI, Umudike, Umuhahia, Abia State, Nigeria 1-12.

Photita, W., P. W. J. Taylor, R. Ford, K. D. Hyde and S. Lumyong. 2005. Morphological and molecular characterization of Colletotrichum species from herbaceous plants in Thailand. Fungal Diversity 18: 117-133.

Rholf, F. J. 1994. NTSYS-pc, numerical taxonomy and multivariate analysis system. Exeter Software, Applied Biostatistics, N.Y. Saharan Africa 432-439.

Sahore, G. J. and N. A. Kamenan. 2007. Changes in nutritional properties of yam (Dioscorea spp.), green plantain (Musa spp.) and cassava (Manihot esculenta) during storage. Food Science and Technology 47: 81-88.

Scott, G. J, M. Rosegrant and C. Ringler. 2000. Roots and tubers for the 21st Century: Trends, projections and policy options. Food, Agriculture and the Environment Discussion. International Food Policy Research Institute (IFPRI) and International Potato Centre (CIP) Washington, D.C, U. S. A. 89 - 97.

Serra, I. M. S., R. S. B. Coelho and M. Menezes. 2008. Physiologic and pathogenic characterization, isozyme analysis of monosporic and multisporic isolates of Colletotrichum gloeosporioides. Summa Phytopathologica 34: 113-120.

Smith, D. and A. H. S. Onions. 1994. The preservation and maintenance of living fungi. $2^{\text {nd }}$ ed. IMI Technical Handbooks No.2, CAB International, Wallingford.

Sutton, B. C. 1992. The genus Glomerella and its anamorph Collectotrichum. Pages 1-26 in: Colletotrichum Biology, Pathology, and Control. J. A. Bailey and M. J. Jeger, eds. CAB International, Wallingfored, UK.

Tjamos, E. C., G. C. Papavisas and R. J. Cork. 1993. Biological control of plant diseases and challenges for the future. Plenum Press, New York, London 462.

Vinod, T. and V. I. Benagi. 2009. Studies on the cultural and nutritional characteristics of Colletotrichum gloeosporioides, the causal organism of papaya anthracnose. Karnataka J. Agric. Sci. 22 (4): 787-789.

Xiao, C. L., S. J. Mackenzie and D. E. Legard. 2004. Genetic and pathogenic analyses of Colletotrichum gloeosporioides isolates from strawberry and noncultivated hosts. Phytopathology 94: 446-453.

Rapid Procedure for the Extraction of DNA from Fungal Spores and Mycelia. Last accessed: October, 2013. 